\title{
Colin Tyler*
}

\section{Forms, Dialectics and the Healthy Community: The British Idealists' Receptions of Plato}

https://doi.org/10.1515/agph-2018-0004

\begin{abstract}
This article counters the dominant misinterpretations of the British idealists' readings of Plato, thereby fundamentally undermining the current historiography of Plato's modern reception in the English-speaking world. Section one introduces the topic, before section two explores the British idealists' celebration of Plato. Section three argues against the fundamental assumption of the current historiography: that the British idealists were dogmatic Neo-Platonic Hegelians. Rather, while the British idealists recognised Plato's sometimes dogmatic formulations of the forms, they saw greater philosophical value in his "searching" texts. They appreciated the provisional, inchoate character of human conceptualisations of the forms and emphasised our responsibility to test them. Section four highlights the British idealists' recognition of Plato's literary turn. Section five demonstrates that, contrary to the received view of Plato scholars, the British idealists themselves were egalitarians who prioritised personal virtue, decentralised debate and local self-determination. I conclude that the British idealists interpreted Plato in ways that differed significantly from Jowett and the current historiography.
\end{abstract}

\section{Introduction}

Through their writings and their influence on curricula and teaching at some of the leading universities of the British Empire, British idealists such as Bernard Bosanquet, Edward Caird, T. H. Green, R. L. Nettleship and D. G. Ritchie and others did much to revitalise philosophical research into Plato's thought. ${ }^{1}$ Together

1 The British universities included Birmingham, Cambridge, Glasgow, Oxford and St Andrew's. Their former pupils spread idealism around the British Empire, through Australian universities

*Corresponding author: Colin Tyler, Centre for Idealism and the New Liberalism, School of Law and Politics, University of Hull, Cottingham Rd, Hull HU6 7RX, United Kingdom; c.tyler@hull.ac.uk 
with their precursor Benjamin Jowett, they helped to extend Plato's significance beyond his already established presence among classical historians, philologists and rhetoricians. ${ }^{2}$ In fact, the received view is that, in John Glucker's words, after the 1860s, "[t]he idealist image of Plato became canonical, and has been taken for granted since, in various shapes and forms, by most students of Plato and ancient philosophy." 3 Even though this influence is cited frequently by historians of the nineteenth-century reception of Plato's thought, only rarely has it been welcomed. In Frank Turner's words, Jowett and the British idealists held that "the task of the interpreter was to glean the unchanging moral truth of the insights of the ancient writers that lay encased in the language and moral conventions of an earlier time and place." ${ }^{4}$ Many critics have alleged that this "dogmatic image" of Plato interpreted him as seeing the forms as capable of being understood (only but fully) by a philosophical elite. ${ }^{5}$ Moreover, it is alleged that the British idealists used Plato's theory of the just polis in The Republic (which entails rule by a benevolent dictatorship) as the basis of their own allegedly conservative theory of the modern healthy community.

Unfortunately, despite the regret voiced regarding the British idealists' alleged influence, intellectual historians with an interest in Plato's reception have written very little on the details of the British idealists' reception of Plato. Moreover, beyond chapters by J. H. Muirhead, primarily regarding F. H. Bradley's metaphysics, and W. J. Mander's recent brief analysis, no intellectual historians with a detailed knowledge of British idealism have considered the movement's debts to Plato and Platonism. ${ }^{6}$ This article seeks to address that significant lacuna, considering the claims mentioned above regarding the forms, and the relationship between the just polis and the modern healthy community.

The gap in the current Plato literature might not be surprising given the misunderstandings and then silence that fell over the British idealists for most of the twentieth century. British idealism was one of the leading philosophical movements in Britain from the 1870s until shortly after the end of the First World

including Adelaide, Melbourne and Sydney, as well as Queen's University, Kingston Ontario, Canada, and the universities of Auckland, Otago and Victoria in New Zealand and Rhodes University College, South Africa.

2 For a negative assessment, see Turner 1993, 359-61. For other attempts to revive philosophical interest in Plato see Turner 1981, chapter eight; Glucker 1996, 395-7, 402-5; Demetriou 2005.

3 Andrews 2011, 458; Demetriou 2002, 70 f.; Demetriou 2005, 63-6; Fite 1934, 2f.; Glucker 1996, 405; Lane 2001, 74 f., 93; Press 2007, 50; Turner 1981, 418, 427 and 432.

4 Turner 1981: 427.

5 Glucker 1996: 405.

6 Muirhead 1931, Part II, chapters V-IX. Muirhead pays passing attention to Bosanquet, Caird and Green, although little to Jowett and none to Nettleship. 
War. ${ }^{7}$ Nowadays, British idealism is usually seen as significant historically for its influence on the early Bertrand Russell and G. E. Moore. Following Russell and Moore's attacks, for much of the twentieth century the movement was thought to endorse mysticism, collectivism, statism and conservatism, as well as valorising the myth of a static homogenised universe. Even though contemporary British idealist scholars have discredited this interpretation among their own research community, the ill-founded reputation that the British idealists retain among non-specialists extends beyond contemporary analytic philosophers and into the historiography of Plato's Victorian reception. It is necessary to address this extension given both the renaissance of interest in British idealist thought over the past thirty years and the influence that their interpretation is alleged to have exerted on Plato scholarship in the English-speaking world.

The article is structured as follows. Section two indicates the importance that the British idealists attached to the careful study of Plato. Section three begins to address the misconceptions which pervade the current historiography of the British idealists' reception of Plato, by arguing against its fundamental assumption: namely, that the British idealists are best understood as dogmatic Neo-Platonic Hegelians. Relatedly, it establishes that while the British idealists did recognise the dogmatic elements of some of Plato's formulations of his theory of the forms, they saw greater philosophical value in his more searching texts. It will be shown that the British idealists recognised the provisional and frequently inchoate character of all actual conceptualisations of the forms and the associated responsibility of every agent to test their particular conceptualisations. Section four demonstrates that the British idealists insisted that, given the provisional nature of all attempts to conceptualise the forms, Plato's writings should be read in cognisance of the fact that he used literary techniques to encourage his audience to engage with the texts philosophically. Building on this acknowledgement that, ultimately, absolute certainty regarding the forms is unwarranted, section five demonstrates that, far from endorsing Jowett's benevolent dictatorship, in ethical, civic and political matters the British idealists were egalitarians who prioritised personal virtue, decentralised democratic debate and local self-determination wherever possible. The article concludes that, contrary to the view that is dominant among historians of the nineteenth-century reception of Plato's philosophy, the British idealists interpreted Plato in ways that differed markedly both from Jowett and from the current historiography, and that each of them endorsed some aspects of what they read in Plato and rejected much else.

7 On the movement's membership and history, see Tyler 2010b and Mander 2011. 
Before commencing, three caveats must be entered. The first caveat is that Jowett is only a marginal figure in this story. Famously, he published three substantial editions of Plato's dialogues during his lifetime and an edition of The Republic appeared posthumously in 1894. Yet, as Mander has observed, philosophically Jowett played a crucial role in the advent of British idealism rather than being one of its number. ${ }^{8} \mathrm{He}$ is included here because, as Mander observes, he ensured that Plato was accorded at least the same significance as Aristotle in the Oxford philosophy curriculum (as distinct from classical studies), and many British idealists worked in the shadow of Jowett's translations and commentaries. Moreover, he might have been influential in that he brought his students to see Plato as inaugurating a tradition of anti-naturalism, a tradition which Hegel and some British idealists helped to develop. ${ }^{9}$ It was this tradition which, he believed, offered the most promising route out of the mid-Victorian "crisis of faith". ${ }^{10}$ The second caveat is that, given the extent and quality of the British idealists' writings on Plato, what follows can address only the main criticisms that have been made of them as interpreters of Plato, rather than exploring anything like the full diversity and detail of their treatments. The constructive work of this article is undertaken against the background of the response to these criticisms. The third caveat is that it is impossible to examine here later British idealist Plato scholars such as Muirhead, or related philosophers such as Ernest Barker, R. G. Collingwood and A. E. Taylor. ${ }^{11}$

\section{Plato's Importance for the British Idealists}

The relative lack of detailed critical analysis of the British idealist reception of Plato might be taken to imply that these idealists themselves did not write much about Plato. Yet, in reality many of the British idealists published substantial analyses of Plato's thought. ${ }^{12}$ In addition to discussions of various lengths and detail scattered throughout their writings, one finds a significant number of intellectually sophisticated articles and addresses concerning Plato, as well as book-

8 Mander 2011, $30 \mathrm{f}$.

9 I am grateful to one of the anonymous reviewers for this suggestion.

10 See, for example Green 1883: "Introduction” and Book I, and Caird 1885.

11 Similarly, it is impossible to compare the British idealists' readings of Plato to contemporaries such as John Stuart Mill. Regarding the latter, see for example Loizides 2013.

12 For bibliographies of Jowett and many British idealists, please email the author (c.tyler@ hull.ac.uk). 
length treatments by Bosanquet, Caird, Muirhead, Nettleship and Ritchie. ${ }^{13}$ All of these idealists were fluent in ancient Greek and worked with the original texts, usually preparing their own translations. Moreover, contrary to the implications of some contemporary Plato scholarship, these treatments were not restricted to The Republic but dealt with the full range of Plato's dialogues, several of them at significant length.

Many contemporary scholars acknowledge what Frank Turner has called George Grote's “industriousness of research, extent of ancient and modern learning, power of analysis, and tenacity of purpose" when interpreting Plato. Yet, they tend both to neglect the British idealists' admiration for Grote and to understate greatly the British idealists' own scholarship and critical acumen. ${ }^{14}$ As Mander has noted, "the British idealists were all deeply versed in ancient philosophy and use it frequently to construct or support their systems." ${ }^{15}$ Nevertheless, as will become clear below, it is misleading to refer to Bosanquet, Caird and Nettleship as “the Balliol Platonists”, as Mander does on occasion (echoing Muirhead), just as it is misleading when Demetriou styles the fifty years following 1880 as a time when "undisguised Platonolatry [was] coming from Oxford and the school of the British Idealists." 16 Indeed, the distance from Plato was pronounced in the writings of some leading members. For example, it is very noticeable that Aristotle appeared in Green's writings far more frequently than did Plato, and, usually when Green discussed Plato, it was simply as a companion or precursor to Aristotle. ${ }^{17}$ It is misleading therefore to emphasise Plato's significance for Green, as some scholars have done. ${ }^{18}$ Neither did Green endorse Neo-Platonism: for Green, Aristotle's superiority over Plato stemmed from the latter's tendency towards mysticism, a tendency that Green argued had a profoundly harmful influence on philosophy for many centuries: "[Aristotle] less frequently lapses into the false dualism of soul and body, mind and matter, ideas and things, which made Plato, against his principles, a mystic, and which has clung like a body of death to Platonising philosophy ever since."19

Despite Green's reservations, Plato was profoundly significant for Bosanquet, Caird, Nettleship and Ritchie, as well as for Jowett. Unfortunately, as noted

13 These works are detailed in the following notes.

14 Turner 1993, 326.

15 Mander 2011, 74.

16 Mander 2011, 77, 79; Muirhead 1931, 14; Demetriou 2002, $61 \mathrm{f}$.

17 Ritchie 1891: 139. Immediately, Ritchie noted that much the same might be said of Hegel, but Ritchie highlighted Green's qualified admiration for Hegel.

18 For example, Lane 2001, $74 \mathrm{f}$. and 79.

19 Green 1997, vol. 3, 47. 
earlier, critics have raised significant objections to the resulting scholarship. Turner criticised their Platonic revivals on four main grounds. First, allegedly the British idealists' adhered to a form of Hegelian historicism; second, allegedly they endorsed what they saw as Plato's dogmatic approach to philosophy; third, allegedly they overestimated the ability of human beings to understand and articulate Platonic forms; and, fourth, allegedly they admired The Republic as a model of benevolent elitism. Much of the subsequent historiography of the British idealist reception of Plato can be placed under these four headings, and much of it accords with Turner's reading, with the only notable divergences relating to humans' capacities to understand the forms. ${ }^{20}$ It will be argued below that once the significant problems with the existing scholarship on the British idealist reception of Plato have been corrected, Bosanquet, Caird, Green, Jowett, Nettleship and Ritchie emerge as subtle non-"Hegelian" (sc. non-historicist and non-hypostatising) Plato scholars with strong liberal instincts, all of whom valued the “searching” aspects of Plato's philosophy that many historians now ascribe not merely to Grote's Plato but to Plato himself. ${ }^{21}$

\section{The British Idealists on Hegel and Neo-Platonism}

The cornerstone of many contemporary attacks on the British idealists can be seen as the allegation that Jowett imposed onto Plato's texts a common set of fixed "Hegelian" forms, which crucially he believed an elite group of human beings would inevitably come to know through the march of an Hegelian Geist or World-Spirit. ${ }^{22}$ Moreover, allegedly Jowett's reading portrayed Plato as a Neo-Platonist, ${ }^{23}$ a reading allegedly that was extended by subsequent generations of British idealist interpreters, particularly Bosanquet and Nettleship, and through them to other twentieth-century interpreters of Plato. Certainly, Muirhead saw a lineage from Plato to Neo-Platonism, as did some sympathisers with British ideal-

20 Demetriou 2002, $63 \mathrm{f}$.

21 On the question of whether Hegel himself should be read in this way, see Tyler 2006, Introduction and chapter one.

22 Turner 1981, 418, 427; Press 2007, 50; Andrews 2011, 458; Fite 1934, 2f.; Demetriou 2002, 70 f. 23 In what follows, "Neo-Platonism" refers to the now-conventional interpretation whereby humans are capable of understanding the forms through (quasi-)mystical apprehension. For a recent defence of the claim that Plato was a Neo-Platonist without being a mystic, see Gerson 2013. I am grateful to an anonymous reviewer for this reference. See also Slaveva-Griffin 2014. 
ism, such as J. A. Stewart and the former British idealist A. E. Taylor. ${ }^{24}$ Otherwise, claims that the British idealists interpreted Plato as a forerunner to Neo-Platonism are controversial for a number of reasons. First, not all British idealists were absolute idealists: for example, McTaggart was a personal idealist. ${ }^{25}$ Moreover, even if British idealists had read Plato as a dogmatist, as Demetriou has observed the "interpretation of Platonism as a fixed body of dogma" was the "long-standing" conventional view even prior to the appearance of Grote's Plato and the Other Companions of Sokrates in $1865 .{ }^{26}$ More than this, there are more fundamental problems with the characterisation of the British idealists as Hegelians, as will become clear in this section.

With much justification, Mander has observed that, for the British idealists, ancient Greek philosophy was "as vital a reference point as Kant or Hegel; and we misunderstand their philosophy, unless we recognize this fact."27 Moreover, he reminds us that even if their subsequent readings of the ancient Greeks were informed by the interpretations of the German idealists, each of the British idealists read Plato and Aristotle "well before they met Hegel". ${ }^{28}$ More than this, Jowett and the British idealists had very complex relationships with Hegel, and it is easy to overstate the degree to which they shared attitudes or debts to each other. ${ }^{29}$ They did agree with Hegel that: "The development of philosophic science as science, and, further, the progress from the Socratic point of view to the scientific, begins with Plato and is completed by Aristotle. They of all others deserve to be called the teachers of the human race." 30 Yet, Jowett and many British idealists did not have the clear and profound debts to Hegel that many Plato scholars impute to them. Indeed, although Bosanquet and Caird endorsed forms of Hegelianism throughout their careers, many other British idealists expressed various serious reservations regarding Hegel's philosophy, as will become evident now.

24 Muirhead 1931, passim. Taylor 1924. On Taylor and Stewart's respective relationships to British idealism, see Mander 2011, 222, 547 n. 96.

25 McTaggart 1934, 273-92; Mander 2011, 369-76. Press 2007, 50, for one mistakenly refers to McTaggart as an absolute idealist.

26 Demetriou 2005, 72, citing Thursfield 1865, 462.

27 Mander 2011, 74.

28 Mander 2011, 74. German Platonism was dominant in the nineteenth century, as was reflected in Grote 1865, vol. 1 passim. I am grateful to Kyriakos N. Demetriou for this point (personal communication).

29 For Jowett's careful analysis of Hegel's philosophy and its relationship to Plato's philosophy, see Jowett 1892c, 316-38.

30 Hegel 1894, vol. 2, part 1 (chapter III, first period, third division). 
By the early-1870s, Jowett had come to believe that an obsession with absolute idealist theology and metaphysics tended to make Balliol students unable to fulfil their duties in this world. ${ }^{31}$ Consequently, he sought to limit the teaching of Hegel in the college. Similarly, F. H. Bradley explicitly eschewed the label "Hegelian”, arguing that rather than trying to build philosophical systems, Hegelian or otherwise, "[w] hat we want at present is to clear the ground, so that English Philosophy, if it rises, may not be choked by prejudice. The ground can not be cleared without a critical, or, if you prefer it, a sceptical study of first principles." 32 In fact, contrary to a core claim of many contemporary attacks on them, like Bradley and the other British idealists, Jowett emphasised the importance, in Caird's words, of "modern criticism on its negative side", something that led them to a deep distrust of dogmatism. ${ }^{33}$ This is not to say that they pursued "modern criticism" in the same ways. For example, Caird articulated Jowett's key claims as follows:

\begin{abstract}
From philosophy, especially the philosophies of Plato and Hegel, [Jowett] gained much, but he seemed hardly to care for their dialectic or for their effort after intellectual synthesis, but only for their manifold views of life and their fertile suggestions as to man's spiritual nature and history. What indeed he prized most in other writers was what is the best in his own work, the inspired gleams of insight, the vivid and epigrammatic expressions of particular aspects of truth, and he prized them still more if they were lighted up with a touch of humour. ${ }^{34}$
\end{abstract}

Contrary to the widespread view then, Jowett replaced a dogmatic approach to philosophy with "an intuitive apprehension of the ethical and religious aspects of life". ${ }^{35}$ It was because of his attraction to such philosophical criticism that Jowett welcomed the publication of Green's introductions to Hume in 1874, introductions of which Nicholas Griffin has observed "few philosophers have ever been so ferociously assailed by their editor [as Hume was by Green]". ${ }^{36}$ Indeed, as Master of Balliol Jowett gave Green a sabbatical for the 1875-76 session so that Green could answer "Bain, H. Spencer, \&c., who are the very Tuppers of philosophy and yet have gained for themselves fame and name." ${ }^{37}$ Green wrote five articles attacking Herbert Spencer and G. H. Lewes, between then and his death in

31 Caird 1897, 45.

32 Bradley 1883, vi (and page $\mathrm{x}$ in the second edition).

33 Caird 1897, 44.

34 Caird 1897, $44 \mathrm{f}$.

35 Caird 1897, 44.

36 Griffin 2013, 384 n. 2.

37 Letter from Benjamin Jowett to Edward Caird, 5 January 1875, in Abbott et al 1899, 190. 
1882, helping to address Jowett's lament over the relative lack of productivity of "we Platonists and Idealists". 38

Not only does this episode undermine still further the received picture of Jowett as a dogmatic, "Hegelian" interpreter of Plato, but it raises important questions regarding Green's own later position regarding Hegel and Plato as well. Even though Green characterised his own philosophy as "Hegelian" in a letter of 1866 , by 1881 he was suggesting to readers of his review of John Caird's Hegelian Introduction to the Philosophy of Religion that the book might "make us feel the need still more strongly of a reconsideration of certain points in Hegel's doctrine". ${ }^{39}$ Only in this way could one avoid making a false "distinction between the exoteric and the esoteric in their spiritual life, against which some of the most weighty of their master's sayings might be invoked." ${ }^{40}$ By the time Green came to write the Prolegomena to Ethics (1878-82; published posthumously in 1883), he had rejected many core Hegelian principles. ${ }^{41}$

As noted above, many Plato scholars link the dogmatic reading of Plato to the British idealists' alleged belief that the Platonic forms or ideas could be fully understood by an intellectual elite, and only by that elite. It is important to emphasise that this is an epistemological issue rather than a metaphysical one: that is, it concerns the human ability to know and articulate the nature of the forms, rather than the metaphysical claim that the forms have a determinate, eternally fixed nature which might or might not be known fully to human beings. The particular epistemological claim that is made frequently by contemporary Plato scholars (that the British idealists believed that an intellectual elite could come to understand the forms fully) is significant because it sheds further light on the ways in which even the most Hegelian of the British idealist interpreters of Plato (Bosanquet and Caird) read Hegel. The first thing to notice is that most contemporary Plato scholars dissent from Turner's claim that Jowett and his disciples were unconcerned by the forms, emphasising instead "the more general turn of mind that 'places the divine above the human, the spiritual above the material, the one above the many, the mind before the body."”42 Rather than endorsing this

38 Letter from Jowett to Caird, 5 January 1875, in Abbott et al 1899, 190. Thomas Hill Green, Introductions to Hume's Treatise of Human Nature”, in Hume 1874; reprinted in Green 1997, vol. 1, 1-370. Green's articles on Spencer and Lewes constitute the remainder of the first volume of Green 1997.

39 "Hegelian philosophy": letter from T. H. Green to James Bryce, 23 March 1866, in Green 1997, vol. 5, 420; Green 1997, vol. 3, 142.

40 Green 1997, vol. 3, 142.

41 See further Tyler 2010a, chapter two.

42 Turner 1981, 420, quoting Jowett 1892b, 19. 
reading of Jowett, the dominant position in the current historiography portrays the British idealists as Neo-Platonists understood as those who, borrowing Burnyeat's characterisation of Thomas Taylor's reading of Plato, sought to construct "a dogmatic Idealist system emanating from a transcendental Unity with which we may aspire to mystic union”. ${ }^{43}$

In fact, and in flat contradiction to this received picture, it was because the British idealists rejected epistemic elitist dogmatism that they saw so much of value in Plato's writings. Certainly, they recognised his occasional tendency to portray the forms as existing independently of human minds, in a more real world of pure ideas. ${ }^{44}$ Yet, most of them insisted that Plato's more typical and more defensible position was that the forms were "not mere creations of our thought", but instead presupposed "what in modern phrase we might call objective validity". ${ }^{45}$ It was in this latter sense (only) that the forms "had an existence independent of minds, because independent of any individual mind at any particular moment." ${ }^{46}$ In other words, they read Plato very much as Hegel read Plato. That is, the forms were both absolutely real and absolutely ideal. Yet, the forms were neither abstract nor unrelated to each other, for in fact they were immanent within the concrete texture of the world experienced by human beings. ${ }^{47}$

This claim was central to the British idealists' interpretation of Plato as an idealist. Yet, they insisted that Plato's idealism was flawed, not least because they believed he retained two incompatible lines of argument even within his late philosophy. Caird expressed the point thus in 1904: first, there was the Plato who insisted on a pronounced metaphysical distinction between the eternal, perfect realm of the forms on the one hand and the changing and imperfect phenomenal world on the other. Simultaneously and in opposition to this dualistic view, Plato defended a position that was far more closely akin to the idealism of British idealists such as Caird and Bosanquet. It is worth quoting Caird at length on this point as he brings out crucial similarities between what he saw as this strand of Plato's idealism and the idealism of many of the British idealists.

[I]f we lay stress upon Plato's synthesis of opposites, upon his attempted reconciliation of Parmenides and Heraclitus, upon his conception of mind as a self-moving principle which produces motion in all other things, and lastly, upon his conception of God as a goodness

43 Burnyeat 1998, 357. See Press 2007, 50. See the description of F. H. Bradley as "a kind of absolute rational pantheism" in Lane 2001, 75.

44 For example, Ritchie 1902, $93 \mathrm{f}$.

45 Ritchie 1902, 93.

46 Ritchie 1902, 93.

47 I am grateful to Bill Mander for this point (personal communication). 
which communicates itself and therefore is the cause of being and well-being to all his creatures, we seem to be brought within sight of an absolute idealism, which transcends all distinctions, even the distinction between the material and the spiritual. ${ }^{48}$

The broader features of the absolute idealist reading of Plato were defended at length, particularly by the more Hegelian of the British idealists. For example in relation to its epistemic aspects, as early as his 1865 review of Grote's magnum opus, Caird rejected Grote's division of Plato's writings into “'Dialogues of Search' and 'Dialogues of Exposition"” on two grounds..$^{49}$ First, every dialogue contained elements of both "search" and "exposition", and second, Grote's division neglected Plato's efforts in works such as the Parmenides and the Philebus to move beyond the purely critical and the purely constructive, to attain a more dialectical form of philosophical enquiry which avoided the reification of ideas ("the hard and petrified theory of ideas, which is usually associated with his name"), while not rejecting the belief in truth. ${ }^{50}$ Caird argued that if Plato had carried through the logic of the mutually defining character of ideas that he began to develop in the Parmenides, the Philebus and the Sophistes, then "he would have been led far beyond that dualist mode of thought" which "fixed a wide gulf of separation between ideas and phenomena, between thought and sensation, between philosophy and art. He would, above all, have abandoned that notion of a brute irrational matter, which hinders the idea from fully realizing itself." ${ }^{51}$ The logical implication of Plato's philosophy was found in the Hegelian "formula, 'All that is rational is real, and all that is real is rational." ${ }^{\prime 52}$ As Nettleship put it, citing Plato: "Things are known and understood so far as they are seen as elements in a rational order; knowledge is the perception of them as such, and things so perceived are truly perceived." ${ }^{53}$ Yet, the real was not merely a self-validating system of abstract ideas; it was the concrete and changing world of actual human life to the extent that that world was the practical manifestation of thought. ${ }^{54}$

Throughout his career, Caird maintained this emphasis on the need to read Plato's writings dialectically as an exercise in both "search" and "exposition", not least by emphasising the need to read those writings in light of their current practical relevance. For example, an unauthorised book of notes taken at his lectures

48 Caird 1904, vol. 1, $253 \mathrm{f}$.

49 Caird 1865, 355.

50 Caird 1865, 368f.

51 Caird 1865, $369 \mathrm{f}$.

52 Caird 1865, 370.

53 Nettleship 1880, 176, citing Plato, Republic, 509b.

54 Caird 1865, 384. 
in approximately 1880 considered the claim that "Plato tried to get away from the particular to the universal, or to reach the universal without accounting for the particular, which certainly gives rise to a form of Mysticism" in which "ideas [are] as fixed and eternal, above relativity and time, having no connection to sensible objects". ${ }^{55}$ Caird objected to this position: "we may say of [these ideas] as Aristotle said about the idea of the good, that they are not intelligible and therefore of no practical use."56

In his preface to the 1903 edition of Jowett's translations of the Socratic dialogues, Caird argued that in the Phaedo "the fertile germ of Socratic thought is developed into the systematic completeness of the Platonic Idealism." 57 Nevertheless, he remained emphatic that Plato's philosophy was at its most valuable when interpreted not as emphasising knowledge of a static set of dogmatically articulated truths, but rather when it prioritised the conception of knowledge as a fluid system with an internal dynamic, upon whose elements students should reflect critically, revising them where they were found to be unclear or inconsistent. This move marked the transition from Socratic criticism to "scientific" (sc. dialectical) enquiry. ${ }^{58}$ In line with the dialectical nature of thought, revising these elements might well also require one to revise the principle of unity which underlies the whole. Caird analysed Plato's role in this transition in many places, not least The Evolution of Theology in the Greek Philosophers (1904), where he traced Plato's own shift from Socratic criticism to the dialectic. Caird argued that Plato was the first person to articulate the fundamental principle of all true philosophy, whereby

\footnotetext{
the universal must be taken neither as the sum of the particulars nor as the abstraction of a common element in them, but as a principle of unity which is implied in them, and which, when discovered and defined will make them intelligible. [...] Nor could Plato be content with the definition of these general terms taken separately. Each of them is the name of a principle of unity within a certain limited sphere, but all special spheres of existence are elements within the one great whole of reality. ${ }^{59}$
}

Every British idealist found at least part of this conception in Plato, but they disagreed regarding his success in implementing the method. For Green and Caird, Plato himself did not overcome fully his conception of human knowledge of the forms as abstract, apparently self-validating and hence fixed, and hence they

55 Auxilium 1886, second series, 8. See Jones et al 1921, 107-112.

56 Auxilium 1886, second series, 8.

57 Caird 1903, ix.

58 Hegel 1894, vol. 2, part 1.

59 Caird 1904, vol. 1, $110 \mathrm{f}$. 
regarded Plato's thought as self-contradictory. Bosanquet held, by contrast, that Plato overcame completely the conception of our knowledge of universals as static and merely "abstract" terms. ${ }^{60}$ For human beings, abstract and static "universality, Plato is about to show, is always self-contradictory and a world of confusion, because its elements have not gone through the process of being reduced to harmony". ${ }^{61}$ Instead, "the true or concrete universal" was "thorough knowledge, tracing the matter in hand to its roots, and obtaining its width at the surface by a mastery of all the ramifications which spring from a connected set of data and principles."62

Similarly, Nettleship argued that Plato recognised the inadequacy of the forms conceived as isolated abstract concepts. ${ }^{63}$ For Nettleship, Plato held that forms had meaning for humans only when conceived as being related to one another to form a harmonious and "organic unity", the construction of which was an end being sought constantly through a dialectical process which both "specifies without separating" (which Ritchie labelled elsewhere "critical" metaphysics) and "follows and reveals the natural articulations of its subject-matter" (which Ritchie labelled "speculative" metaphysics). ${ }^{64}$ At any particular time, the thinker's understanding of each form had the status of a hypothesis, to be tested by its coherence within a system ordered by a scale of principles (forms) which ultimately made up a coherent whole. ${ }^{65}$ When discerning the relations between forms: one "get[s] out of the region of 'hypotheses,"” by "see[ing] truth as a whole of parts". ${ }^{66}$

This dialectical method of continually seeking to analyse, reconstruct and then test one's formulation of the organic unity required the philosopher to possess a constantly searching attitude, thereby entailing the rejection of dogmatism. It was because Plato developed this method that all of the British idealists regarded him as the "father" of their own enquiring form of idealism, or as Caird put it, as "the fountainhead of idealistic, we might even say of ideal, views of life." 67 This was the true conception of idealism, "which is the best corrective to mysticism", in that

60 Bosanquet 1906, 205 (commenting on Plato, Republic, 474c-475e).

61 Bosanquet 1906, 205.

62 Bosanquet 1906, 205.

63 Nettleship 1880, 147-62.

64 Nettleship 1880, 151.

65 Nettleship 1880, $148 \mathrm{f}$. This aspect of Plato's thought laid the basis for Collingwood's metaphysics, especially Collingwood 1933.

66 Nettleship 1880, 150.

67 Caird 1904, vol.1, 58. 


\begin{abstract}
[it] seeks not merely to get away from the temporal and the finite, but to make them intelligible; not to escape from immediate experience into an ideal world in comparison with which it is a shadow and a dream, but to find the ideal in the world of experience itself, underlying it, and giving a new meaning to all its phenomena. ${ }^{68}$
\end{abstract}

In this regard, all of the British idealists anticipated many contemporary scholars by distancing Plato from the Neo-Platonists. For example, Ritchie began his 1902 Plato by noting that "I have followed Grote and Jowett, and, indeed, most modern scholars, in seeking to keep the image of Plato free from Neo-Platonic incrustations". ${ }^{69}$ The latter he characterised as "the more elaborate, more systematic, and more speculative system of the Neo-Platonists" who built upon Cicero's development of the New Academy ${ }^{70}$ He traced intrusions of later traditions into the Platonic tradition from Stoic, Syrian, Oriental, Jewish and Christian sources. At times, Ritchie observed, the subsequent association of older, cruder and often mystical forms of thought with the name of Plato, made it more accurate to label "Neo-Platonism" "Neo-Pythagoreanism". ${ }^{71}$ Ritchie welcomed the revival of serious scholarship based on Plato's original texts, which he saw as a continuing project to strip away the errors that misled the Cambridge Neo-Platonists and even early nineteenth-century scholars such as Thomas Taylor who interpreted "Plato through the mists of Neo-Platonic enthusiasms". ${ }^{72}$

Ritchie welcomed the fact that Plato was being read again not dogmatically but dialectically, and therefore as an inspiration for later philosophers' own thoughts, an approach that best honoured Plato and Aristotle by being "their most genuine, because their most independent, disciples." ${ }^{73}$ Similarly, even though Muirhead went so far as to link the development of idealism in nineteenth-century Britain to the development of the Cambridge Platonists, he did not claim that this link was one of direct or even indirect influence, but merely that both movements drew out elements of the Platonic tradition that infused British and American culture more generally. The "coincidence" of view was "noteworthy as an illustration of the national bent that has all along given a special character to Anglo-Saxon idealism." 74

68 Caird 1904, vol.1, 60.

69 Ritchie 1902, vi; see also Ritchie 1902, 125-27 and 187.

70 Ritchie 1902, 186.

71 Ritchie 1902, 189f.; see also Caird 1904, vol. 1, $256 \mathrm{f}$.

72 Ritchie 1902, 193-5.

73 Ritchie 1902, 196.

74 Muirhead 1931, 14. Mander claims that Muirhead 2011, 73f., believed British idealism emerged out of Cambridge Platonism. 
So far, this section has established the error in the widespread convictions (i) that most of the British idealists missed or marginalised the searching elements of Plato's philosophy, and (ii) that they embraced what allegedly they saw as a dogmatic faith in the individual's ability to understand a more real universe of abstract and essentially isolated forms. In fact, while Green read Plato in this way, he went on to condemn Plato for failing to understand the dialectical nature of thought. Nevertheless, Green has been shown to be unusual in that the remaining British idealists recognised the searching, dialectical Plato. This has been shown to be particularly true of Bosanquet, Caird, Nettleship and Ritchie.

That the British idealists rejected the dogmatic reading of Plato has very significant implications for the current history of his reception in nineteenth-century Britain. Consider, for example, Glucker's claim that the academic dominance of the "dogmatic image promoted by Jowett and other idealists" retarded for many generations the much more fruitful and accurate sceptical reading. ${ }^{75}$ Clearly, given the prevalence of this contrast in the Plato literature, Glucker's complaint is very significant, as is the scholarly care with which, in reality, the British idealists explored and promoted not so much a "sceptical" approach to Plato but rather a "searching” or "enquiring” approach, one that assumed complete knowledge to be possible in principle even if some elements constantly eluded human beings in practice.

In fact, as was indicated by their dialectical Plato, the British idealists were just as alive to the enquiring aspects of Plato's philosophy as are many contemporary Plato scholars. In this way, they saw the majority of Plato's texts as invitations to engage in philosophical activity, rather than as articulations of a static body of doctrine that students should learn and passively endorse. As Nettleship observed, "certainly no one can be further than Plato from the idea that 'dialectic' is a ready-made system of formulas to be swallowed whole by the mind."76 Metaphysics was a continuing process of constructing and revising a complete and harmonious system from one's current understanding of universals. ${ }^{77}$ Consequently, the British idealists emphasised the side of Plato that extolled what Demetriou has characterised as "a remarkable awareness of the diversity of human intellectual experience", and rather regretted when Plato adopted "the gloomy guise of a preceptor or a priest."78 Ultimately then, the British idealists valued three key aspects of Plato's philosophy. The first was the provisional character

75 Glucker 1996, 405.

76 Nettleship 1880, 165.

77 For example, Ritchie 1893, $140 \mathrm{f}$.

78 Demetriou 2005, 72. Demetriou 2005, 80-97, does not make the same judgement about the British idealists. 
of our conceptions of the forms. The second was his recognition of our limited ability to articulate these forms clearly. The third was his acknowledgment of our limited ability to construct a coherent whole from our conceptualisations of the forms. In this sense and reinforcing the argument developed in this section, Grote's searching Plato was far more attuned to the critical attitude of the British idealists than current Plato scholars allow. As the next section will establish, this kinship was reflected in the idealists' preferred method of reading Plato as a philosopher with significant literary skills.

\section{Plato, Poetry and the Philosopher}

Glucker argues that "the dogmatic image [of Plato] promoted by Jowett and other idealists" prevented the emergence of "an important and seminal new method" of reading Plato wherein "the dialogue [is treated] as an organic unity in which drama, narrative, characters and philosophical arguments work together for the purpose of achieving a philosophical discourse in a concrete, human (albeit larger than life) situation."79 Despite the vehemence of Glucker's attack, many of the idealists championed precisely the approach he defends. The meeting of metaphysics and poetry was highlighted also in Jowett's preface to his English translations of Plato's dialogues as well as underlying many of the British idealist readings. Hence, Jowett described Plato as "the poet or maker of ideas": "He is no dreamer, but a great philosophical genius". ${ }^{80}$ In his 1865 review of Grote's Plato and the Other Companions of Sokrates, Caird berated William Whewell for "the barbarism that allows him [...] to dismember and re-arrange a work [such as The Republic] which has the unity of a poem, as well as of a philosophical treatise."81 The implication of such passages in Jowett and the British idealists was clear: one could not reach a correct understanding of Plato's philosophy if one neglected or misunderstood its inner literary dynamics. ${ }^{82}$ In his 1880 essay on Plato's Republic, Nettleship cautioned the reader that,

\footnotetext{
[n]either the later uses of the word 'philosophy,' nor its literal interpretation as 'love of wisdom,' will much help the modern reader to enter here into the spirit of Plato. Philosophy to most of us is too much wrapt up in the associations of books and systems, of technicalities and jargon, to let us feel the living spirit which it still is when it is anything more than
}

79 Glucker 1996, 405.

80 Jowett 1892a, xi; see also Caird 1904, vol. 1, 93, 119, 147 and $201 \mathrm{f}$.

81 Caird 1865, 351.

82 Jowett 1892a, ix. 
a set of phrases. [...] When he [Plato] spoke of 'the truth,' or of 'what is,' we see that there entered into his feeling not only the enthusiasm of the scientific discoverer, but also the passion of the poet for beauty and the devotion of the saint to the object of his worship. ${ }^{83}$

To understand Plato properly, one must read him as a master of various literary forms. Developing this point in his 1885-88 lectures, Nettleship reminded his readers that

Plato stands between Socrates and a modern writer on philosophy. [...] The literary function of the Platonic dialogue is in modern literature distributed between different kinds of books, chiefly between books of philosophy, and novels, in which ideas grow, embodied in the lives of the characters. ${ }^{84}$

Nettleship explored the ways in which Plato supplemented the dialogue form with various other literary devices, including introducing a "dramatic element" to his argument and presenting the various positions under discussion "in a picturesque manner". ${ }^{85}$ Consequently, Nettleship reminded the reader, one should always bear in mind the literary character of Plato's writings, for it was only in this way that one could uncover the philosophical arguments and debates they developed. In short, as a classicist and a philosopher well-versed in the techniques of Biblical criticism employed by Hegelian theologians and others including his former teachers Jowett and Green, Nettleship was just as alive as Glucker to the need to read Plato in full cognisance of the fact that Plato employed these literary devices to convey the humanity of the philosophical enterprise. ${ }^{86}$ This was not a marginal point, because philosophy derived its particular life from the particular modes of reflective life which shaped the individuals who engaged in it.

Despite allegations to the contrary then, the British idealists argued that one should be sensitive to the literary techniques Plato employed because these techniques were the means through which Plato conveyed the inherently dynamic nature of human thought. As was shown in section three, this dynamism reflected three crucial features of Plato's philosophy: the provisional character of our conceptions of the forms; Plato's recognition of our limited ability to articulate these forms clearly; and his acknowledgment of our limited ability to construct a coherent whole from our conceptualisations of the forms. As Nettleship and others emphasised, everyone could be taught to reason dialectically, and it was their

83 Nettleship 1880, 85.

84 Nettleship 1897, vol. 1, 8 f.

85 Nettleship 1897, vol. 1, 8 f.; see also Nettleship 1880, 124-26.

86 See further Green 1997, vol. 3, 20-45; Dale 2014, 239-57. 
constant searching that constituted "the living expression of the truth itself, the embodied logic of reality". ${ }^{87}$ As will become clear in the next section, the British idealists' refusal to make unassailable ontological claims had significant implications for their critical attitudes towards Plato's political philosophy as well as for their own politics.

\section{Idealist Anti-Platonic Politics: Personal Virtue and Localism}

Many contemporary historians of Plato's nineteenth-century reception claim that the British idealists endorsed the benevolent elitism that they (the British idealists) believed Plato derived from his belief that the forms could be fully understood and articulated by an intellectual elite, and only by that elite. ${ }^{88}$ In so doing, many critics allege, Jowett in particular adopted a form of Hegelian historicism in which "the task of the interpreter was to glean the unchanging moral truth of the insight of the ancient writers that lay encased in the language and moral conventions of an earlier time and place." ${ }^{89}$ It was for this reason, allegedly, that Jowett felt justified in excluding Plato's endorsement of homosexuality from his translation of The Symposium..$^{90}$ Relatedly, there is a broad consensus among the contemporary scholars of Plato's nineteenth-century reception that, due to the importance of spirituality and dialectical thinking in the British idealist conception of the best human life, Jowett's reforming Plato was thoroughly collectivist in his attitude to the polis. ${ }^{91}$

Many contemporary scholars argue that Jowett's reading bolstered the prejudices of the British idealists, all of whom, in Turner's words, "sought to forge a spiritual and ideological ideal of the state as a countervailing force against the social and moral dissolvents of commercialism and modern natural right philosophy". ${ }^{92}$ The individual was to forego his or her private desires and plans in favour

87 Nettleship 1880, 156 f., 151.

88 Andrews 2011, 458; Demetriou 2002, 70 f.; Fite 1934, 2f.; Lane 2001, 74 f., 93; Turner 1981, 418, 427; Press 2007, 50.

89 Turner 1981, 427.

90 Lane 2001, 82.

91 Demetriou 2002, 63f., 71f.; Glucker 1996, 405; Lane 2001, 100-2, 149; Turner 1981, 420, 42748. By contrast, Burnyeat (1998, 363-7) acknowledges Jowett's scholarship and liberal social reformism.

92 Turner 1981, 427. 
of "an ethic of self-sacrifice and duty to a higher collective social good." 93 Thus, Jowett used Plato to justify the sacrifice of individuality in the name of benevolent rule by a socially conscious elite. The critics argue that in this way, and ignoring a few minor interpretative differences, the British idealists saw "obvious resonances of their own elitism and collectivist ideal of the state in Plato, and they then imposed on Plato their own moral intentions and political goals." 94 Some scholars go further, linking the British idealists' ethics to their alleged project of "socialist reform", whereby the chaos of individual freedoms is overcome by the true freedom of benevolent organisation. ${ }^{95}$

This consensus regarding the British idealists' social and political philosophy is as misguided as the consensus upon which it rests regarding the capacity of an elite to understand the forms. As will be established in this section, none of the British idealists except F. H. Bradley followed Jowett in endorsing Plato's benevolent elitism, a position that in reality, they regarded as being wholly inappropriate for late-nineteenth century Britain, Europe, North America and Australasia. Rather, except for the relatively apolitical Nettleship and the reactionary Bradley, not merely were they ethical, civic and political radicals but in these spheres they were egalitarians. ${ }^{96}$ All of them, even Bradley, were very conscious of the archaic nature of Plato's practical recommendations and consequently of their limited applicability to late-Victorian and Edwardian society. This came through nowhere more clearly than in their commentaries on The Republic. The depth and significance of their criticisms of that work are understated by many contemporary scholars who, as noted already, have criticised the British idealists for allegedly over-emphasising the importance of The Republic. In fact, the British idealists were interested in a very significant range of Plato's texts beyond The Republic.

It is important to appreciate that The Republic held a special significance for the British idealists primarily on pedagogic grounds: it covered a significant range of topics in a manner that engaged undergraduate students' interests, and indeed it continues to do so. It was for this reason that Nettleship and Bosanquet's commentaries on The Republic were so popular with both university teachers and students, in a way that the commentaries on other texts were (and are)

93 Turner 1981, 420.

94 Turner 1981, 428.

95 Demetriou 2002, 63. For the same criticism made in relation to their readings of Fichte, see Tyler 2015.

96 See for example, Anderson 1991; Leighton 2004, chapters five and six; Tyler 2006: chapters two, three and four. 
not. Moreover, The Republic was easily available in a cheap students' edition, translated by John Llewelyn Davies and David James Vaughan. ${ }^{97}$

Ultimately, pedagogical concerns were important to the British idealists because they wanted citizens to become skilled in the methods of dialectical engagement with all fields of knowledge as well as all collective institutions and norms. Consequently, it should be no surprise that Bosanquet, Caird and Nettleship argued at length in their pedagogical texts that The Republic should be read not as a set of dogmatic principles which students should learn almost by rote, but rather that it was an educational text to be used in training students to think and question independently. In that sense, Plato's writings should inform modern educational practice. ${ }^{98}$ Relatedly, educational provision should be based on the aptitudes and talents of the individual, not their wealth, gender or privilege. ${ }^{99}$

Rather than following the benevolent elitist Jowett, ultimately the British idealists drew inspiration for their social and political philosophies from Green's egalitarian thought and practice. Hence, to understand the social and political philosophy of Bosanquet, Caird, Nettleship and Ritchie, one should begin by recalling their shared Greenian dialectics. It was established in section three that British idealist philosophy rested on a process whereby, first, commonly held beliefs were analysed into their most basic constituent abstract universal categories (or forms) and relations ("critical metaphysics"), and then those universals were related to one another so as to form a complete and harmonious system ('speculative metaphysics"). ${ }^{100}$ This system should then be used to re-interpret the concrete world of human experience from which metaphysics began. ${ }^{101}$ If the forms (i) were unclear or (ii) could not constitute a complete and harmonious system, then either the philosopher had made a mistake in his or her analysis or synthesis, or (iii) the world was imperfect. Most likely, it was evidence of all three types of problem, thereby highlighting the need for even greater care in the first two cases, and practical and intellectual reform in the third.

Awareness of these imperfections underpinned the discussion of "The Greek and the Modern Conceptions of Virtue" which formed a cornerstone of Green's

97 Coincidentally, Vaughan was Green's maternal uncle.

98 For example, Bosanquet 1900, 1-26 passim; Caird 1894; Nettleship 1880, 86, 99-107, 122-26, 132-34, 158, 164 f, 168-71 and 179f. Plato's continuing pedagogical significance was emphasised by the Philosophic Radicals as well. I am grateful to Kyriakos Demetriou for highlighting this similarity (personal communication).

99 For example, Nettleship 1880, 137-139; Green 1997, vol. 3, 475 f.; Tyler 2012a, 177-82.

100 Ritchie 1893, 14-8; Seth 1883; Tyler 2010a, chapter five.

101 Green 1997, vol. 2, section 23. 
magnum opus, his posthumously published (in 1883) Prolegomena to Ethics. ${ }^{102}$ There, Green praised Plato and other ancient Greek philosophers, particularly Aristotle, for being the first to articulate "principles on which the good citizen, if he thought the matter out, would find that he had already been acting."103 These principles were taken over in Christianity, where they were developed more fully than was possible for Plato and Aristotle. For example, by the 1880 s fortitude had become as much a virtue of the social reformer as it was of the ancient Greek citizen-soldier, and self-denial was owed to a far wider range of civil associations than the Greek owed to the polis. ${ }^{104}$

In line with his adherence to his dialectics, Green did not blame Plato and Aristotle for their limited appreciation of the demands of the virtues. There were always limits to any individual or group's ability to see beyond the morality of their time. A society with a relatively simple structure must have a similarly simple morality, whereas the more internally differentiated and complex societies of later times created more internally differentiated and complex moralities. Moral values and demands could not avoid being formulated more crudely in ancient Athens than in modern societies, because as a historical fact (rather than an inevitable "Historical" fact), later societies were more complex than ancient Athens. The moral demands were "richer and fuller" in modern societies precisely because "[t]he range of faculties called into play" by active citizenship "must be much wider, when the material to be dealt with consists no longer of supposed chattels but of persons asserting recognised rights, whose welfare forms an integral element in the social good". ${ }^{105}$ Consequently, rather than endorsing Jowett's benevolent elitism, Green was a radical egalitarian democrat. ${ }^{106}$ He saw no end to the processes of social criticism and reform: "every progress achieved opens up a further vista of possibilities still unrealised. In consequence the attainment of true good presents itself to men under new forms. The bettering of human life, though the principle of it is the same now as in the Socratic age, has to be carried on in new ways", and the demands it creates "are far more comprehensive and wide-reaching". ${ }^{107}$

Moreover, contrary to what several Plato scholars have claimed about him, Green was emphatic that social structures were not separate from or "above"

102 Green 1883, sections 246-85.

103 Green 1883, section 250.

104 Green 1883, sections 258 and 264.

105 Green 1883, section 258.

106 See Tyler 2006, chapter two; Tyler 2012a, chapter eight.

107 Green 1883, section 257. See Lane 2001, 93 f. 
individuals and social sub-groups. ${ }^{108}$ Instead, such structures were created, sustained and reformed intersubjectively within the daily life of the community. ${ }^{109}$ Consequently, the domination inscribed within these structures was also inscribed within the individuals, and vice versa. In that this domination kept individuals apart, it hindered the development of individuals. Yet, this domination was in constant conflict with the drive within every individual - whether man, woman, master, slave, capitalist, peasant or worker - to enjoy "the full exercise or realisation of the soul's faculties in accordance with its proper excellence, which was an excellence of thought, speculative and practical."110 Individuals could flourish only through their continuing free interactions as conscientious citizens acting in the ways that they judged to be the best methods to express the highest capacities of themselves and their fellow citizens. The process was one of practical interaction and public dialogue between all citizens through local communities, trade unions and a plethora of other voluntary groups that citizens created for themselves, rather than being a process led by an elite body of philosopher-kings or guardians. This was one reason for Green's belief that, no matter how impressive the lives and work of some Ancient Greeks, they could not justify the cost of their production: namely, "the degradation of human society outside that group" which resulted from slavery and the "seclusion of the Greek communities from the mass of mankind". ${ }^{111}$

These essentials of Green's social and political philosophy were endorsed by every subsequent British idealist, with only minor philosophical variations of emphasis but with more significant practical differences. Caird and Ritchie were important representatives of two approaches in this regard. ${ }^{112}$ Here, the discussion will focus on one of the best-known interpreters of Plato who was also one of the British idealists' most controversial social and political thinkers: Bernard Bosanquet. ${ }^{113}$ Several contemporary Plato scholars place significant weight on Bosanquet's claim in The Philosophical Theory of the State from 1899 that "there is no sound philosophy which is not an embodiment of Plato's conception." "114 They interpret this to mean that Bosanquet endorsed a statist position that was imbued with mysticism, in line with the dogmatic, authoritarian reading of The Republic. Yet, such a reading has been discredited by recent Bosanquet scholar-

108 For example, Andrews 2011, $447 \mathrm{f}$. and 458.

109 Green 1883, sections 180-92.

110 Green 1883, section 254.

111 Green 1883, sections 273f.; see 270-275; see also Tyler 2012a, 65-9.

112 Tyler 2010c; Tyler 2012b.

113 Famously, Bosanquet was attacked in Hobhouse 1918.

114 Bosanquet 1923, 6. 
ship. ${ }^{115}$ Contrary to the impression given by critics, when Bosanquet wrote that "there is no sound philosophy which is not an embodiment of Plato's conception”, he was discussing social ontology rather than political authority. He was endorsing Plato's claim that the individual expresses his or her highest capacities only by living in "healthy" communities, by which he meant communities that provided their members with social roles which matched their innate talents. Hence, Bosanquet argued the following.

[Plato's theory implies] that every individual mind must have its qualities drawn out in various ways to answer to - in fact, to constitute - the relations and functions which make up the community; and that in this sense every mind is a mirror or impression of the whole community from its own peculiar point of view. The ethical assumption or principle of Plato's conception is, that a healthy organisation of the commonwealth will involve, by a necessary connection, a healthy balance and adjustment of qualities in the individual soul, and vice versa. ${ }^{116}$

In short, Bosanquet endorsed the ethical theory that was stated most clearly and famously by F. H. Bradley. This theory combined a conception of the individual as a socially embedded being (the theory of "my station and its duties") with the categorical requirement of critical citizenship that was contained in Bradley's notion of "ideal morality". ${ }^{117}$ This approach recalled Plato: for example, "a man who could not live in his ordinary round of duties" would be "useless to himself and to society." 118 Quoting Bosanquet, Muirhead noted that Bosanquet felt "the existence in and around his old Northumbrian home of a 'real social will,' as 'the completer fact in which the private will finds forms' and as containing the whole secret of "the art of living together'". ${ }^{119}$ The ideal world could not be something separate from the concrete world of our daily practices, rather ideals existed only when they were given form and content through actual daily interactions of real people ("you and I, here and now", in Rawls' words). ${ }^{120}$ Yet, Bosanquet did not equate the present world with the ideal world: he saw much that was wrong with the way we live together. ${ }^{121}$ The social reformer was morally required to seek to improve the society in which he or she lived, rather than being rendered inert by

115 For example, Nicholson 1990, Study VI; Sweet 1997; Tyler 2006, chapter four.

116 Bosanquet 1923, 7.

117 Bradley 1927, essays 5 and 6; Nicholson 1990, Study 1.

118 Plato, The Republic, 407d-e (Cornford trans.), quoted in Sweet 1997, 66 n. 11.

119 Muirhead 1935, 47, quoting Bosanquet 1924, 52.

120 Rawls 1999, 30.

121 Bosanquet explored this claim repeatedly in his writings, but good short statements can be found in Bosanquet 1891, 92-107 and 108-30. 
a recognition of the fact that their society was a messy historically conditioned entity.

Repeatedly, explicitly and firmly, Bosanquet rejected the mystical reading of Plato, and argued “against one's hazy expectations and in opposition to the current and more or less popular legends of his meaning". ${ }^{122}$ In reality, "[t]he law of value as he [Plato] laid it down for all time, 'that which is filled with the more real, is more really filled,' together with his doctrine of the increasing concreteness and vital stability of the higher experiences, made an end of dualism in principle". ${ }^{123}$ "The modern wilderness of interests" required most of us to fulfil the requirements of more than one station in life in complicated ways, unlike ancient citizens whose societies were far simpler and whose duties were correspondingly far clearer. ${ }^{124}$ How the modern citizen would best fulfil these requirements could be decided only in practice and on a case-by-case basis. ${ }^{125} \mathrm{Green}$, Bosanquet and the other British idealists argued at length that in stable countries, the best course for most citizens was to honour their established social duties, while seeking to amend their rights and duties wherever their particular consciences and practical judgement told them that this was morally required and possible. In oppressive societies rebellion might not be merely the citizen's right but possibly their moral duty. ${ }^{126}$

Hence, Caird was active in the movement against British actions in South Africa in the 1890s, while Nettleship, Ritchie and particularly Bosanquet supported Irish Home Rule, with Bosanquet arguing in June 1893 that “constitutional or parliamentary government in Ireland is really a huge hoax, which by itself is enough to drive any thinking Irishman into fury and rebellion." ${ }^{127}$ Ritchie argued that the individual became a person by being an active citizen of a stable community which gave everyone a reasonable chance of developing their respective highest potentials. ${ }^{128}$ Such a community was a concrete historically situated and complex whole of particular practices. Ritchie argued that Plato fell far short of this concrete egalitarian ideal: "It is not because he makes his citizens merge their lives in the life of the community that his ethics is inadequate, but because his

122 Bosanquet 1924, $54 \mathrm{f}$.

123 Bosanquet 1924, $54 \mathrm{f}$.

124 Bosanquet (ed.) 1895, 1-27.

125 Bosanquet 1900, 90, 91 n. 5.

126 For example, Green 1997, volume 2, sections 98-112; Tyler 2012a, chapter eight.

127 Letter from Bernard Bosanquet to Caroline Bosanquet, June 1893, in H. Bosanquet 1924, 102 (see H. Bosanquet 1924, 99-102); on Caird, see Tyler 2010c; Ritchie 1891, 129 f.; Bradley 1901, note on page xxix.

128 Ritchie 1902, 177-79. 
conception of the community is too abstract and too much limited by the presuppositions of aristocratic Hellenism." "129 In fact, liberal radicalism in its differing forms stood at the heart of the social and political thought of Bosanquet, Caird, Green, Nettleship and Ritchie.

Their liberal radicalism puts the lie to Lane's claim that the British idealists "look[ed] up to Plato as a model for political and moral leadership." ${ }^{130}$ It unsettles Lane's contrast between the British idealists' allegedly conservative politics ("the endorsement of existing moral and political values") and allegedly more radical approaches which "call for the invention of new moral values, deeper and richer than those of existing polities". ${ }^{131}$ (Lane's reading is ambiguous however, as elsewhere she claims that "The original Oxford-issue, idealist Plato was [...] a political one, but political only in the vague sense of supporting moral commitments to reform." $)^{132}$

Lane claims that "in the halcyon days of Balliol”, "[t]he idealist Plato" was "safe from the cut and thrust of mundane politics". ${ }^{133}$ Whether or not they thought Plato wished to avoid practical politics, the idealists themselves could not have been further from Lane's characterisation of them. The British idealists (excluding Bradley) were emphatic regarding the need for concrete expression of their philosophy in radical politics. In the political landscape of their times, Green and Caird were politically active Radicals (and in their own terms they were republicans in a mould closely akin to their hero Giuseppe Mazzini as well as anticipating what later Hobhouse would call "liberal socialists") who worked hard to extend higher education opportunities to women, to extend the franchise and, in Green's case, for temperance reform. ${ }^{134}$ Similarly, Bosanquet was a leading member of the Charity Organisation Society (which emphasised individual responsibility supported by carefully targeted charity) and, like Sydney Ball, Ritchie was a Fabian socialist. ${ }^{135}$ Nettleship shared their egalitarian democratic sympathies and their heroes such as Giuseppe Mazzini, Abraham Lincoln and John Bright, although without the same degree of personal passion for the practice of local and municipal politics and social reform. ${ }^{136}$ In spite of the assumptions of Plato scholars, none of them was a Jowett-style benevolent liberal elitist, and all were radicals

129 Ritchie 1893, 149.

130 Lane 2001, 128.

131 Lane 2001, 128.

132 Lane 2001, 118.

133 Lane 2001, 118.

134 See Tyler 2006, chapter two; Tyler 2010c; Tyler 2012a.

135 Den Otter 2007; Tyler 2010b.

136 Bradley 1901, xxviii-xxix. 
except for F. H. Bradley whom Richard Wollheim describes as 'deeply conservative or reactionary. ${ }^{137}$

Caird voiced the feelings of the remainder of the movement when he told Sir Henry Jones that "Class distinctions have become something purely artificial and must be broken down." 138 This applied in relation to education and all other forms of social life. It was for this reason that so many of the idealists worked to extend educational opportunities to women and the poor, both through political campaigning and exercising their own power within their respective universities. These were continuing processes, for, as Green observed in the Prolegomena, "Faculties which social repression and separation prevent from development, take new life from the enlarged co-operation which the recognition of equal claims in all men brings with it”. ${ }^{139}$ This inclusive civil society was given life through active citizenship for all, with individuals taking the lead in local, municipal and national government and self-help organisations such as cooperatives and trade unions, as well as undertaking charitable work and a whole range of other altruistic activities.

This section has established that far from being benevolent elitists in the Jowett mould, the British idealists excluding Bradley were not merely academics but also practical radical social reformers and democrats. They played leading parts in university and temperance reform (Caird and Green), social policy provision (Bosanquet) and political causes (Green and Ritchie). Their philosophically informed radical practice led them to distance themselves from the degree and type of repression they believed underpinned Plato's theory of self-discipline, which had also been evident in Jowett's exclusion from his translation of The Symposium of Plato's apparent endorsement of homosexuality. ${ }^{140}$ The justification for these very practical and time-consuming activities they found in Plato's (somewhat self-contradictory) writings: as Bosanquet observed, "Freedom, the absence of obstruction within and without, is the key-note of the Republic."141 Whether in philosophy or in practical reform, the key process was one of continuing dialectical engagement with the messy realities of the world, and not least with the obscurities and obstructions to free human life which one found there. In relation to Plato's philosophy, this was the politics they associated with a theory which conceived our understanding of the forms to be often inchoate, always provisional and incapable of constituting a perfectly complete and internally consistent whole.

137 Wollheim 1969, 14.

138 Edward Caird quoted in Jones et al. 1921, 149; see also Jones et al. 1921, 114-18.

139 Green 1883, section 208.

140 See Tyler 2012a, chapter four; also Nettleship 1880, 99f., 105-07, $112 \mathrm{f}$.

141 Bosanquet 1900, 66 n. 5; see also Bosanquet 1900, 83 n. 6, 99 n. 5. 


\section{Conclusion}

The British idealists have been condemned for perverting the study of Plato for much of the twentieth century, a distortion that allegedly continues until the present day. As noted at the start of this article, frequently the British idealists have been blamed for promoting the views both that Plato believed a possible intellectual elite could understand the forms fully, and that he advocated the related theory of the just polis as being ruled by a benevolent dictatorship. Moreover, it has been alleged that the British idealists themselves used Plato's theory of the polis as the basis of their own allegedly conservative theory of the well-ordered modern state. The present article has disputed all of these widely made claims. It has shown the flaws in the critics' assumption that the British idealists are best understood as dogmatic Neo-Platonist Hegelians. It has been established that, while the British idealists recognised the dogmatic elements of certain of Plato's works, they saw greater philosophical value in his more "enquiring" texts. The British idealists recognised the importance of Plato's use of literary techniques to encourage his audience to engage with texts philosophically, and it was shown that, rather than advocating Jowett's Plato-inspired benevolent dictatorship, the British idealists were ethical, civic and political egalitarians who prioritised personal virtue, decentralised democratic participation and local self-determination. Consequently, it is vital to return to the British idealists in full cognisance of the fact that they interpreted Plato in ways that differed markedly both from Jowett and from the current historiography, and that each of them endorsed some aspects of what they read in Plato while rejecting much else. ${ }^{142}$

Abbott, E./Campbell L. (eds.) 1899. Letters of Benjamin Jowett, M.A. Master of Balliol College, Oxford. London.

Anderson, O. 1991. “The Feminism of T. H. Green: A Late-Victorian Success Story?". History of Political Thought 12, 671-93.

Andrews, K. 2011. "Walter Pater as Oxford Hegelian: Plato and Platonism and T. H. Green's Prolegomena to Ethics". Journal of the History of Ideas 72, 437-60.

142 I am pleased to thank the following for their comments on earlier drafts: Russell Bentley, Michaelle Browers, Jim Connelly, Kyriakos N. Demetriou, Maria Dimova-Cookson, Jeremy Dunham, Antony Hatzistavrou, Melissa Lane, Mathieu Marion, Peter Nicholson, Jean-Paul Rosaye, Avital Simhony, Andrew Vincent, Jonathan Westgrove and particularly Bill Mander, as well as members of both the Triangle Research Seminar at the National Humanities Center, Durham, NC, USA and the Yorkshire Ancient Philosophy Network. The usual disclaimer applies. 
Auxilium. 1886. An Aid to the Study of Moral Philosophy. Specially designed for student preparing for examination. First, Second, and Third Series in One Volume. Preliminary Edition. Glasgow.

Bosanquet, B. (ed.) 1895. Aspects of the Social Problem. London.

-. 1891. Essays and Addresses. Second edition. London.

-. 1900. The Education of the Young in The Republic of Plato. Cambridge.

-. 1906. A Companion to Plato's Republic for English Readers. Second edition. London.

-. 1923. The Philosophical Theory of the State. Fourth edition. London.

-. 1924. "Life and Philosophy". In Contemporary British Philosophy: Personal Statements, First Series. Ed. J. H. Muirhead. London/New York, 51-74.

-. 1924. Bernard Bosanquet: A Short Account of His Life. London.

Bradley, A. C. 1901.“Biographical Sketch”. In Philosophical Remains. Ed. R. L. Nettleship. Second edition. London, xi-lviii.

Bradley, F. H. 1883. The Principles of Logic. London.

-. 1927. Ethical Studies. Second edition. Oxford.

Burnyeat, M. F. 1998. "The Past in the Present: Plato as educator of nineteenth-century Britain". In Philosophers on Education: Historical Perspectives. Ed. A. O. Rorty. London, 353-73.

Caird, E. 1865. "Plato and the other Companions of Socrates". North British Review 43, 351-84.

-. 1885. The Social Philosophy and Religion of Comte. Glasgow.

-. 1894. Address on 'Plato's Republic as the Earliest Educational Treatise'. Bangor.

-. 1897. "Professor Jowett". International Journal of Ethics 8, 40-47.

-. 1903. "Preface”. In Benjamin Jowett (trans.), The Four Socratic Dialogues of Plato. Oxford, v-xi.

-. 1904. The Evolution of Theology in the Greek Philosophers. 2 volumes. Glasgow.

Centre for Idealism and the New Liberalism. University of Hull. 2011. 'Resources' (http://www2.hull.ac.uk/fass/politics-and-international-stu/research/research-centres/ $\operatorname{cinl} /$ resources.aspx).

Collingwood, R. G. 1933. An Essay on Philosophical Method. Oxford.

Dale, L. 2014. “T. H. Green and the Modern Novel”. Modern Language Quarterly 75, 239-57.

Davies, M./Helgeby, S. 2014. "Idealist Origins: 1920s and Before”. In G. Oppy/N.N. Trakakis (eds.). History of Philosophy in Australia and New Zealand. Dordrecht, 15-54.

Demetriou, K. N. 2002. “A 'Legend' in Crisis: The Debate over Plato's Politics, 1930-1960". Polis 19, 61-91.

-. 2005. "The Revival of a Legend: The Debate over Plato in Nineteenth-Century Britain". Quaderni di storia 61, 59-101.

Den Otter, S. 2007. “ 'The Restoration of a Citizen Mind': Bernard Bosanquet and the Charity Organisation Society”. In Bernard Bosanquet and the Legacy of British Idealism.

Ed. W. Sweet. Toronto/Buffalo/London, 33-49.

Fite, W. 1934. The Platonic Legend. New York/London.

Gerson, L. P. 2013. From Plato to Platonism. Ithaca/London.

Glucker, J. 1996. "The Two Platos of Victorian Britain”. In Polyhistor: Studies in the History and Historiography of Ancient Philosophy. Eds. K. A. Algra/P. W. van der Horst/D. T. Runia. Leiden/New York/Köln, 385-406.

Green, T. H. 1874. Introductions to Hume's Treatise of Human Nature”. In David Hume, Works, 4 vols. Ed. T. H. Grose/T. H. Green. London.

-. 1883. Prolegomena to Ethics. Ed. A.C. Bradley. Oxford.

-. 1997. Works. 5 vols. Ed. R. L. Nettleship/P. P. Nicholson. Bristol. 
Griffin, N. 2013. "Russell and Moore's Revolt Against British Idealism". In Oxford Handbook of the History of Analytic Philosophy. Ed. M. Beaney. Oxford, 383-406.

Grote, G. 1865. Plato and Other Companions of Socrates. 3 vols. London.

Hegel, G. W. F. 1894. Lectures on the History of Philosophy. Three volumes. Trans. E. S. Haldane/F. H. Simson. London.

Hobhouse, L. T. 1918. The Metaphysical Theory of the State: A criticism. London.

Jones, Sir H./Muirhead, J. H. 1921. The Life and Philosophy of Edward Caird, LL.D., D.C.L. Glasgow.

Jowett, B. 1892a "Preface to the First Edition”. In Dialogues. Plato. Trans. B. Jowett. 5 volumes. Third edition. Oxford, vol. 1, ix-xii.

-. 1892b. “Meno: Introduction”. In Dialogues. Plato. Trans. B. Jowett. 5 volumes. Third edition. Oxford, vol. 2, 3-25.

-. 1892c. "Sophist: Introduction and Analysis". In Dialogues. Plato. Trans. B. Jowett. 5 volumes. Third edition. Oxford, vol. 4, 283-338.

Lane, M. 2001. Plato's Progeny: How Plato and Socrates still Captivate the Modern Mind. London.

Leighton, D. P. 2004. The Greenian Moment: T. H. Green, Religion and Political Argument in Victorian Britain. Exeter.

Loizides, A. 2013. J. S. Mill's Platonic Heritage: Happiness Through Character. Lanham.

Mander, W. J. 2011. British Idealism: A history. Oxford.

McTaggart, J. M. E. 1934. Philosophical Studies. Ed. S. V. Keeling. London.

Muirhead, J. H. 1931. The Platonic Tradition in Anglo-Saxon Philosophy. Studies in the History of Idealism in England and America. London.

-. (ed.) 1935. Bernard Bosanquet and his Friends. London.

Nettleship, R. L. 1880. “The Theory of Education in Plato's Republic”. In Hellenica: A collection of essays on Greek Poetry, Philosophy, History and Religion. Ed. E. Abbott. London, 67-180.

-. $\quad$ 1897. Philosophical Lectures and Remains. Ed. A. C. Bradley/G. R. Benson, 2 volumes. London.

Nicholson, P. P. 1990. Political Philosophy of the British Idealists: Selected Studies. Cambridge.

Press, G. R. 2007. Plato: A Guide for the Perplexed. London.

Rawls, J, 1999. The Law of Peoples, with "The Idea of Public Reason Revisited". Cambridge Mass./London.

Ritchie, D.G. 1891a. Darwinism and Politics. Second edition. London.

-. 1891b. The Principles of State Interference: Four Essays on the Political Philosophy of Mr. Herbert Spencer, J. S. Mill, and T. H. Green. London.

-. 1893. Darwin and Hegel, with other Philosophical Studies. London.

-. 1902. Plato. Edinburgh.

Seth, A. 1883. "Philosophy as the Criticism of Categories". In Essays in Philosophical Criticism. Eds. A. Seth/R. B. Haldane. London, 8-40.

Slaveva-Griffin, S. 2013. Review of Lloyd P. Gerson, From Plato to Platonism. Notre Dame Philosophical Reviews. 7 October 2014 (http://ndpr.nd.edu/news/52961-from-plato-toplatonism/).

Sweet, W. 1997. Idealism and Rights: The Social Ontology of Human Rights in the Political Thought of Bernard Bosanquet. Lanham.

Taylor, A. E. 1924. Platonism and its Influence. London.

Thursfield, J. R. 1865. “Mr Grote’s Plato”. Westminster Review 84, 459-82. 
Turner, F. M. 1981. The Greek Heritage in Victorian Britain. New Haven/London.

-. 1993. Contesting Cultural Authority: Essays in Victorian Intellectual Life. Cambridge.

Tyler, C. 2010a. Metaphysics of Self-realisation and Freedom: Part 1 of The Liberal Socialism of Thomas Hill Green. Exeter.

-. 2010b. 'The British Idealists'. In Colin Matthew, Brian Harrison and Lawrence Goldman (eds.) Oxford Dictionary of National Biography. Oxford.

-. 2010c. "The Liberal Hegelianism of Edward Caird: Or, how to Transcend the Social Economics of Kant and the Romantics". International Journal of Social Economics 37, 852-66.

-. 2012a. Civil Society, Capitalism and the State: Part 2 of The Liberal Socialism of Thomas Hill Green. Exeter.

-. 2012b. “D. G. Ritchie on Socialism, History and Locke”. Journal of Political Ideologies 17, 259-80.

-. 2015. "Individuality, Freedom and Socialism: The British Idealists' Critiques of the Fichtean State”. Political Studies 63, 319-35. 